\title{
A RÉSZVÉNY- ÉS DEVIZAPIACOK VOLATILITÁSÁNAK TOVAGYŨRŨZÓ HATÁSAI A KÖZÉP- ÉS KELET-EURÓPAI ORSZÁGOK GYAKORLATI TAPASZTALATAI ALAPJÁN
}

Ngo Thai Hung

Exponenciális általánosított autoregresszív feltételes heteroszkedaszticitású (EGARCH) modellt alkalmazunk arra, hogy megfigyeljük az aszimmetrikus volatilitásnak a részvény- és devizapiac közötti, tovagyürüző hatását a válság előtti és utáni magyar, lengyel, cseh, román, valamint horvát piacok vizsgálatával. A tanulmány a 2000. április 1-jétől 2017. szeptember 29-ig terjedő időszakot fedi le. A vizsgálat kimutatta, hogy a részvény-, valamint devizapiacokon a volatilitásnak ez a tovagyürüző hatása két irányban érvényesült a magyar piacon a teljes megfigyelési időszakban, Lengyelországban pedig a válság utáni időszakban. A volatilitás egyirányú tovagyürüzése a válság előtti horvát piacokon volt tapasztalható, Csehországban pedig mind a két időszakban a részvénypiacok voltak hatással a devizapiacokra. A válság utáni Horvátországban azonban a vizsgált piacokon nem volt érzékelhető begyürüző hatás. A vizsgálat során keletkezett empirikus eredmények értékes információkat tartalmazhatnak befektetőknek, multinacionális vállalatoknak és gazdaságpolitikai döntéshozóknak pénzügyi döntéseik meghozatalakor.

JEL-kódok: $\mathrm{C}_{15} ; \mathrm{F}_{31} ; \mathrm{G} 15$

Kulcsszavak: volatilitás tovagyürüzése, kelet-közép-európai országok, ARCH, GARCH, EGARCH, devizaárfolyam, részvénypiac

\section{BEVEZETÉS}

A részvény-, valamint a devizapiacok kölcsönös kapcsolata már számos egyetemi kutató és szakember érdeklődését felkeltette, így igen alapos ismeretekkel rendelkezünk a folyamatról. Széles körben elfogadottnak tekintjük azt a tényt, hogy a nemzetközi pénzügyi piacok a közelmúltban jelentősen intergrálttá váltak. A pénzügyi eszközök számának drasztikus emelkedése nagy mértékben fokozta

1 Ngo Thai Hung a Budapesti Corvinus Egyetem Pénzügy Tanszékének PhD-hallgatója. 
a külföldi fizetőeszközök iránti keresletet és kínálatot is. Ez az egymásrautaltság a valuták iránti kereslet és a részvényforgalom megnövekedéséből adódik, ami végső soron hatással van az értékpapírok és valuták közti függőségre is. Kanas (2000) azt is kimutatta, hogy az egymásrautaltság nagyfokú növekedése elősegíti a volatilitásnak a részvény- és devizapiacok közötti átgyürűzését. A pozitív és szignifikánsnak számító begyürüzési hatások növelhetik a nemzetközi befektetők által érzékelt, nem rendszerszintű reziduális portfóliókockázatot, aminek a hatására csökkenhet a portfóliódiverzifikációból származó haszon mértéke. Valójában a volatilitásvizsgálatok segítenek megérteni azokat az információs mechanizmusokat, amelyek fellelhetők a tanulmányban szereplő pénzügyi piacokon, beleértve a piacok közti tovagyürüzési hatásokat, a deviza- és részvénypiacokon fellelhető sokk terjedését, valamint a fedezési stratégiai problémákat is (Aloui, 2007).

Az újabb keletű pénzügyi kiadványok nagy hangsúlyt fektetnek a részvénypiaci és devizapiaci megtérülések kapcsolatára, mivel mind a két változó meghatározó szerepet tölt be a portfóliókiválasztásnál és a gazdasági növekedésben. Az elmélet a részvény-, valamint devizapiaci megtérülések alapján két csatornát különít el egymástól. Az első megközelítést az árfolyamok folyamatorientált modelljének nevezzük (Dornbusch-Fischer, 1980). E megközelítés szerint pozitív kapcsolat áll fenn az árfolyamok és a tőzsdei árak között, ami főként a folyó fizetési mérlegben és kereskedelmi mérlegben összpontosul. A második megközelítést az árfolyamok részvénytőke-orientált modelljének nevezik (Frankel, 1983), amely szerint maga az árfolyam a pénzügyi eszközök - többek között a részvények és kötvények - keresletének és kínálatának az alakulásához igazodik. Az elmúlt években a volatilitás begyürűzését a két pénzügyi piacra, különböző országokra vetítve rengeteg kutató vizsgálta. Ez a tanulmány azonban elhatárolódik a korábbi kutatási eredményektől. Rengeteg elemzés keletkezett a fejlett, valamint feltörekvő országokról, az olyan fejlődő piacokról azonban, mint Magyarország, Lengyelország, Csehország, Románia és Horvátország, csupán két kutatás található (Morales, 2008 és Fedorova-Saleem, 2010). Morales tanulmányában a volatilitás tovagyűrüző hatását a magyar, lengyel, cseh és szlovák piacokon vizsgálta a válság előtt és után, Fedorova-Saleem tanulmánya pedig szintén a válság előtti és utáni időszakot kutatta, a piacok közötti begyürüzést pedig Lengyelországra, Magyarországra, Oroszországra és Csehországra szűkítette le. A mostani tanulmány ezekhez hasonlóan a magyar, lengyel, cseh, román és horvát piacokat vizsgálja mind a válság előtti, mind a válság utáni időszakban.

Cikkünk az EGARCH-modellt hívja segítségül néhány fontos kérdés megválaszolására. Az első ilyen vizsgált terület a napi hozamok feltételes volatilitásának aszimmetrikus és tartós hatása a tőzsdei árfolyamokra a kelet-közép-európai országokban, mind a válság előtt, mind az után. A második fontos kérdés az, hogy 
a korábban említett két pénzügyi piac közti kapcsolat valóban létezik-e ezekben az országokban. Végezetül összehasonlítjuk a kapott eredményeket az országok és időszakok között.

Írásunk a következőképpen épül fel: a következő egységben (2. fejezet) a fontosabb szakirodalom áttekintése történik, a 3. fejezetben pedig az EGARCH-modellt fejtjük ki bővebben. A 4. fejezet az EGARCH-modell becsült eredményeit mutatja be részletesen, végül az 5. fejezetben összefoglaljuk eredményeinket, és levonjuk a megfelelő következtetéseket.

\section{IRODALMI ÁTTEKINTÉS}

A volatilitás tovagyürüzésének mechanizmusa, azon belül is az árfolyamok és részvénypiacok közötti kapcsolat vizsgálata több tanulmány témája. Nem feledkezhetünk meg olyan elméleti keretrendszerekről (Diebold-Yilmaz, 2009; 2012; 2014), mint például az általánosított VAR, amely a részvények hozamokra és az indexek volatilitására irányította a figyelmet. Ezek a munkák azonban az aszimmetrikus tulajdonságra nem tértek ki. A mi kutatómunkánk éppen ezért használja a közgazdaságtanban igen nagy népszerűségnek örvendő GARCH modellezési „Családot”, mert az képes megragadni ezeknek a tovagyürűzéseknek az információs mechanizmusát.

Korábbi kutatómunkák szintén igénybe vették ezt az általánosított ARCH(GARCH-) modellt, hogy vizsgálni tudják a volatilitás begyűrűzését két pénzügyi piac figyelembevételével, különböző országokban. Ezekből a tanulmányokból egyértelműen kitűnik, hogy a volatilitás továbbgyűrűző hatása háromféle lehet: a két piac közötti kétirányú volatilitás továbbgyürüzése; a részvénypiac egyirányú hatása a devizapiacra, valamint fordítva; illetve a nem tartós begyűrűzés két pénzügyi piac között.

Az első tanulmány, amely a volatilitásnak ezt a továbbgyűrűző hatását napi adatok felhasználásával vizsgálta (Kanas, 2000) az 1986. január 1-je és 1998. február 28-a közti időszakot vette referenciaidőszaknak, és 6 fejlett országot vizsgált. Ezt a hat országot - az Egyesült Államokat, az Egyesült Királyságot, Japánt, Németországot, Franciaországot és Kanadát - vizsgálva, kétváltozós EGARCH-modellt használt a feltételes varianciák kiszámításához. A hatból öt ország esetén bizonyítottan kimutatta a továbbgyürüzést, amely a részvényhozamoktól indult a valutaárfolyamok irányába, Németországnál azonban nem tapasztalt ilyen maradandó begyürüzéseket.

Yang-Doong (2004) szintén kétváltozós EGARCH-modellt alkalmazott. Ö 1979. május 1-je és 1999. január 1-je közötti heti adatokkal dolgozott; a várható érték, valamint a volatilitás továbbgyürüződő hatásának a természetét vizsgálta a 
G7-országok részvény- és devizapiacára fókuszálva. A kutatás eredményeképpen empirikusan bizonyította és ténylegesen kimutatta a volatilitás aszimmetrikus továbbgyürüzését a részvénypiacról a devizapiacra Franciaországban, Olaszországban, Japánban és az Egyesült Államokban.

Aloui (2007) egyrészt az amerikai és néhány meghatározó európai piac (Franciaország, Németország, Belgium, Spanyolország, Olaszország) részvény- és devizapiaci adatainak az átlagát és volatilitását (szórását), valamint a két piac közötti oksági kapcsolatot vizsgálta. Az adatbázist az adott országok deviza- és részvénypiacainak napi záróárai alkották. Az aszimmetrikus volatilitás tovagyürűzést egy többváltozós, kiterjesztett EGARCH-modell segítségével mutatta be. A modell segítségével kimutatta, hogy a piacok között aszimmetrikus és tartós a volatilitásátgyürüzés, valamint megmutatta a két piac hozamai és szórásai közötti oksági kapcsolatot mind az euró bevezetése előtti, mind az utána következő időszakban. Továbbá a szerző megerősítette azt a tényt, hogy a részvényhozamok hatása erősebb a devizaárfolyamokra mindkét részmintában.

A volatilitás továbbgyürüzését a részvényhozamok és devizaárfolyamok között Morales (2008) tanulmányozta négy közép-kelet-európai ország (Magyarország, Csehország, Lengyelország és Szlovákia) vizsgálatával. A szerző 1999 és 2006 közötti napi adatokat használt. Ezt az időszakot kettébontotta az euró bevezetése előtti és utáni időszakra. A tényleges vizsgálathoz EGARCH-modellt alkalmazott; a kutatás eredménye nem mutatott ki szignifikáns volatilitás-továbbgyűrüzést ezekben az országokban. Azonban - annak ellenére, hogy ez a továbbgyürüző tulajdonság nem volt kimutatható egyik időszakban sem -, az uniós csatlakozás után ez a begyürüző tendencia még csökkent is mindegyik piacon.

Fedorova-Saleem (2010) a dinamikus volatilitás begyürüző hatását vizsgálta olyan fejlődő közép-kelet-európai országok részvény- és devizapiacain, mint Lengyelország, Magyarország, Oroszország és Csehország. A heti hozamokat a kétváltozós GARCH-BEKK-modell segítségével elemezte. Az eredmények azt mutatták, hogy közvetlen kapcsolat áll fenn az értékpapírpiacok között mind a volatilitást, mind a devizapiacokat tekintetve. A devizapiacoktól a részvénypiacok felé tartó, egyirányú volatilitás-átgyűrűzés volt megfigyelhető mindenhol, a cseh piac kivételével.

Valls-Chuliá (2014) többváltozós aszimmetrikus GARCH-modellt használt a volatilitás begyürüzési hatásainak vizsgálatára. A vizsgálat 2893 ázsiai részvény-, valamint devizapiaci napi adatot tartalmazott 2003 és 2014 között. Az ezekből számított eredmény kétirányú volatilitás-továbbgyűrűzést mutatott ki minden piacon, függetlenül az országok fejlettségi szintjétől.

Mozumder et al. (2015) a volatilitás begyürüzését három fejlett (Írország, Hollandia, Spanyolország) és három feltörekvő ország (Brazília, Dél-afrikai Köztársaság, Törökország) heti adatainak felhasználásával vizsgálta a gazdasági világválság 
előtti, közbeni és utáni időszakokra. A vizsgálat kétváltozós EGARCH-modell felhasználásával történt. A kutatás eredménye, hogy az aszimmetrikus volatilitás továbbgyűrűződése mind a két pénzügyi piacon jelen volt, függetlenül az ország fejlettségi szintjétől a válság idején. Pontosabban, az eredmények azt sugallták, hogy egyirányú volatilitás-továbbgyürüződés ment végbe a részvénypiacok irányából a fejlett országoknál, a feltörekvő országoknál azonban ez a továbbgyürüződés épp fordítva történt meg. Brazíliában mind a két piacon kétirányú gyürüződés volt kimutatható.

Ezzel egyidejűleg Segal és szerzőtársai (2015) olyan empírikus módszertant javasoltak, amelyben a volatilitáson belül megkülönböztetik a „jó” és a „rossz” bizonytalanságból származó hatásokat. Az eredményekből azt a következtetést lehetett levonni, hogy a „jó” bizonytalanság növeli, míg a „rossz” bizonytalanság csökkenti a vizsgált makrováltozót. Így az eszközértékek a jó bizonytalansággal növekedésnek indulnak, rossz bizonytalanság esetén pedig csökkennek.

Jebran és Iqbal (2016) empirikusan vizsgálta a volatilitás részvény- és devizapiacok közötti továbbgyürüzésének a dinamikáját az ázsiai piacokra vetítve (Kína, Hongkong, India, Japán, Pakisztán, Srí Lanka) EGARCH-modell segítségével. A tanulmány 1999. január 4-e és 2014. január 1-je közötti napi adatokkal dolgozott. A kutatás kétirányú aszimmetrikus volatilitás-továbbgyűrűzést mutatott ki a pakisztáni, kínai, hongkongi és srí lankai részvény- és devizapiacokon. Indiában a részvénypiacról a devizapiacra ható, egyirányú volatilitásáttételt figyeltek meg. Japán esetén azonban egyik piacon sem volt kimutatható a továbbgyürüzés hatása.

Ezzel egyidejűleg Baruník és szerzőtársai (2016) kutatása hét szektorból a leginkább likvid amerikai részvények adatain alapult. A volatilitás továbbgyürűzésének aszimmetriáját vizsgálva megmutatták, hogy az egyes részvények szintjén a „jó” és a „rossz” volatilitás tovagyürűző hatása különböző nagyságrendű. Továbbá a kutatásból az is kiderült, hogy az amerikai helyi piacokon a részvények kapcsolódása a válság idején lényegesen növekedett.

Az előzőekben bemutatott irodalmi áttekintésből kiderül, hogy nincs egységes megállapítás a volatilitás továbbgyűrűzéséről. Különböző időszakokat vizsgálva, valamint különböző országokat tekintve eltérő eredményeket kapunk. A jelen tanulmány ezeket a munkákat kívánja kiegészíteni a kiválasztott országok devizaés a részvénypiacainak modellezésével. A fenti piacok volatilitásának kapcsolatát EGARCH-modellel vizsgáljuk. A korábbi kutatások csupán a részvény- és devizaárfolyam-eloszlások első momentumára koncentráltak, ezzel szemben a jelen kutatás a volatilitásra fókuszál. További hozzáadott értéket jelent a napi mintavétel: a válság előtti 9 év és az azt követő 10 év napi adatait használtunk fel, szemben a korábbi heti, illetve havi adatok vizsgálatával, így pontosabb képet kaphatunk arról, hogy a válság mekkora hatással volt kutatási kérdésünkre. Végezetül a vizsgálat 
során keletkezett empirikus eredmények értékes információkat tartalmazhatnak befektetőknek, multinacionális vállalatoknak és gazdaságpolitikai döntéshozóknak pénzügyi döntések meghozatalakor.

\section{MÓDSZERTAN}

\subsection{Adatok}

A modellhez felhasznált adatok öt közép-kelet-európai ország napi részvény-, illetve devizaárfolyamának 2000. április 1 és 2017. szeptember 29. közötti záróértékéből adódnak. A teljes időperiódust azonban további két időszakra bontottuk: 2000. április 1. és 2008. augusztus 29. közötti, a válság előtti időszakra, valamint a 2008. szeptember 1. és 2017. szeptember 29. közötti, a válság utánira. A napi adatokon keresztül pontosabb képet kaphatunk a részvény- és devizaárfolyamok viselkedéséről a korábbi heti és havi mintavételen alapuló kutatások eredményeinél (Jebran és Iqbal, 2016), valamint a két változó közötti dinamika is érthetőbbé válhat számunkra (Agrawal et al., 2010). A magyar, lengyel, cseh, román és horvát piacokat, részvényindexeiket vizsgáltuk: ezek rendre a Budapesti Értéktőzsde - BUX, Varsói Értéktőzsde - WIG, Prágai Értéktőzsde - PX, Bukaresti Értéktőzsde - BET és a Zágrábi Értéktőzsde. Ezen országok nemzeti fizetőeszközei a magyar forint (HUF), a lengyel złoty (PLN), a cseh korona (CZK), a román lej (RON) és a horvát kuna (HRK). A felhasznált devizaárfolyam pedig mindegyik országnál az amerikai dollárral szembeni árfolyam. Mivel a tőzsdék heti 5 napban müködnek hétfötől péntekig, a devizapiacok pedig 6 kereskedési napban állnak a rendelkezésre (a nemzeti ünnepek és hétvégék kivételével), így előzetesen szükséges volt ezeknek a részvényindexeknek és devizaárfolyamoknak az egymáshoz igazítása. Az adatokat a Bloomberg rendszerén keresztül értük el, az összeállításban a Budapesti Corvinus Egyetem Befektetések és Vállalati Pénzügy Tanszéke segédkezett.

A napi hozamokat a következőképpen számoltuk ki: $R_{i, t}=100 \times \ln \left(P_{i, t} / P_{i, t-1}\right)$, ahol $P_{i, t}$ a piaci ár ( $i=1$ a részvényidexek értéke és $i=2$ a devizaárfolyamok értéke) a $t$-edik időpontban. Az 1. ábra, valamint az 1. és 2. táblázat mutatja a válság előtti és utáni árfolyamfolyamatokat és az azokat leíró statisztikákat. Látható, hogy az öt ország részvényárfolyamainak, valamint devizaárfolyamainak volatilitása robbanásszerűen növekedett. 


\section{1. táblázat}

A napi részvényindexek leíró statisztikája

\begin{tabular}{lccccc}
\hline Országok & Magyarország & Lengyelország & Csehország & Románia & Horvátország \\
\hline \multicolumn{5}{c}{ Panel A. Válság elötti időszak } \\
Átlag (\%) & 0,04 & 0,03 & 0,05 & 0,11 & 0,07 \\
SD (\%) & 1,39 & 1,30 & 1,26 & 1,78 & 1,39 \\
Ferdeség & $-0,0883$ & $-0,2559$ & $-0,1862$ & $-0,1390$ & 0,5367 \\
Csúcsosság & 4,3107 & 5,1726 & 5,4575 & 21,9218 & 16,726 \\
Jarque-Bera & $157,88^{* *}$ & $449,76^{* *}$ & $559,39^{* *}$ & $313320^{* *}$ & $16342,68^{* *}$ \\
PP-teszt & $-44,47^{*}$ & $-44,92^{*}$ & $-44,96^{*}$ & $-43,33^{*}$ & $-44,93^{*}$ \\
ADF-teszt & $-44,49^{*}$ & $-44,79^{*}$ & $-44,96^{*}$ & $-43,36^{*}$ & $-44,92^{*}$ \\
N & 2166 & 2166 & 2173 & 2099 & 2069 \\
& & Panel B. Válság utáni idöszak & & \\
Átlag (\%) & 0,02 & 0,02 & $-0,01$ & 0,01 & $-0,02$ \\
SD (\%) & 1,62 & 1,22 & 1,4927 & 1,52 & 1,18 \\
Ferdeség & $-0,1033$ & $-0,5254$ & $-0,6210$ & $-0,7250$ & 0,0734 \\
Csúcsosság & 11,4429 & 7,9297 & 20,3306 & 15,5740 & 27,2175 \\
Jarque-Bera & $6746,18^{* *}$ & 2407,276 & $28642,34^{* *}$ & $15240^{* *}$ & 55425,20 \\
PP teszt & $-45,07^{*}$ & $-34,53^{*}$ & $-39,97^{*}$ & $-44,89^{*}$ & $-44,53^{*}$ \\
ADF teszt & $-35,42^{*}$ & $-42,73^{*}$ & $-44,53^{*}$ & $-44,93^{*}$ & $-25,32^{*}$ \\
N & 2270 & 2274 & 2277 & 2283 & 2268 \\
\hline
\end{tabular}

Megjegyzés: SD - (standard) szórás. N - megfigyelések száma.

A kritikus értékek 1\%, 5\% és 10\%-nál rendre -3,43,-2,86 és -2,56. PP a Phillips-Perron-tesztet jelöli. Az ADF a Kiterjesztett Dickey-Fuller-teszt. ${ }^{* *}$ jelöli az 5\%-os szignifikanciaszintet, ${ }^{\star}$ jelöli azt az esetet, amikor $p<1 \%$.

Forrás: a szerző 


\section{2. táblázat}

A devizaárfolyam hozamainak leíró statisztikája

\section{Országok Magyarország Lengyelország Csehország Románia Horvátország}

Panel A. Válság előtti időszak

$\begin{array}{lccccc}\text { Várható } & -0,0196 & -0,026 & -0,033 & 0,0129 & -0,02 \\ \text { érték (\%) } & 0,78 & 0,6937 & 0,7049 & 0,6516 & 0,69 \\ \text { SD (\%) } & 0,4141 & 0,2921 & 0,0008 & 0,9338 & -0,0863 \\ \text { Ferdeség } & 5,1554 & 5,3131 & 4,2452 & 20,066 & 5,0085 \\ \text { Csúcsosság } & 513,65^{* *} & 140,39^{* *} & 25778,4^{* *} & 350,36^{*} \\ \text { Jarque-Bera } & 960,48^{* *} & -43,80^{*} & -47,20^{*} & -48,94^{*} & -50,02^{*} \\ \text { PP-teszt } & -46,89^{*} & -43,80^{*} & -47,19^{*} & -48,80^{*} & -49,99^{*} \\ \text { ADF-teszt } & -46,89^{*} & 2166 & 2173 & 2099 & 2069 \\ \text { N } & 2166 & & & \\ & & \text { Panel B. Válság utáni idöszak } & & \\ \text { Várható } & 0,02 & 0,02 & 0,01 & 0,02 & 0,01 \\ \text { érték (\%) } & 1,0559 & 1,04 & 0,85 & 0,77 & 0,69 \\ \text { SD (\%) } & 0,1971 & 0,2039 & -0,1349 & 0,2228 & -0,0347 \\ \text { Ferdeség } & 6,0054 & 6,6307 & 8,3099 & 6,6083 & 5,6903 \\ \text { Csúcsosság } & 869,04^{* *} & 1264,76^{* *} & 2681,99^{* *} & 1257,42^{* *} & 684,43^{* *} \\ \text { Jarque-Bera } & -47,65^{*} & -47,85^{*} & -48,39^{*} & -45,12^{*} & -47,68^{*} \\ \text { PP teszt } & -47,61^{*} & -47,71^{*} & -48,38^{*} & -34,59^{*} & -47,68^{*} \\ \text { ADF teszt } & 2270 & 2274 & 2277 & 2283 & 2268 \\ \text { N } & & & & & \end{array}$

Megjegyzés: SD - (standard) szórás. N - megfigyelések száma.

A kritikus értékek 1\%, 5\% és 10\%-nál rendre -3,43,-2,86 és -2,56. PP a Phillips-Perron-tesztet jelöli. Az ADF a Kiterjesztett Dickey Fuller teszt. ${ }^{* *}$ jelöli az 5\%-os szignifikancia szintet, ${ }^{*}$ jelöli azt az esetet, amikor $p<1 \%$.

Forrás: a szerző 
1. ábra

A válság előtti és utáni részvényindex, valamint árfolyamszintek
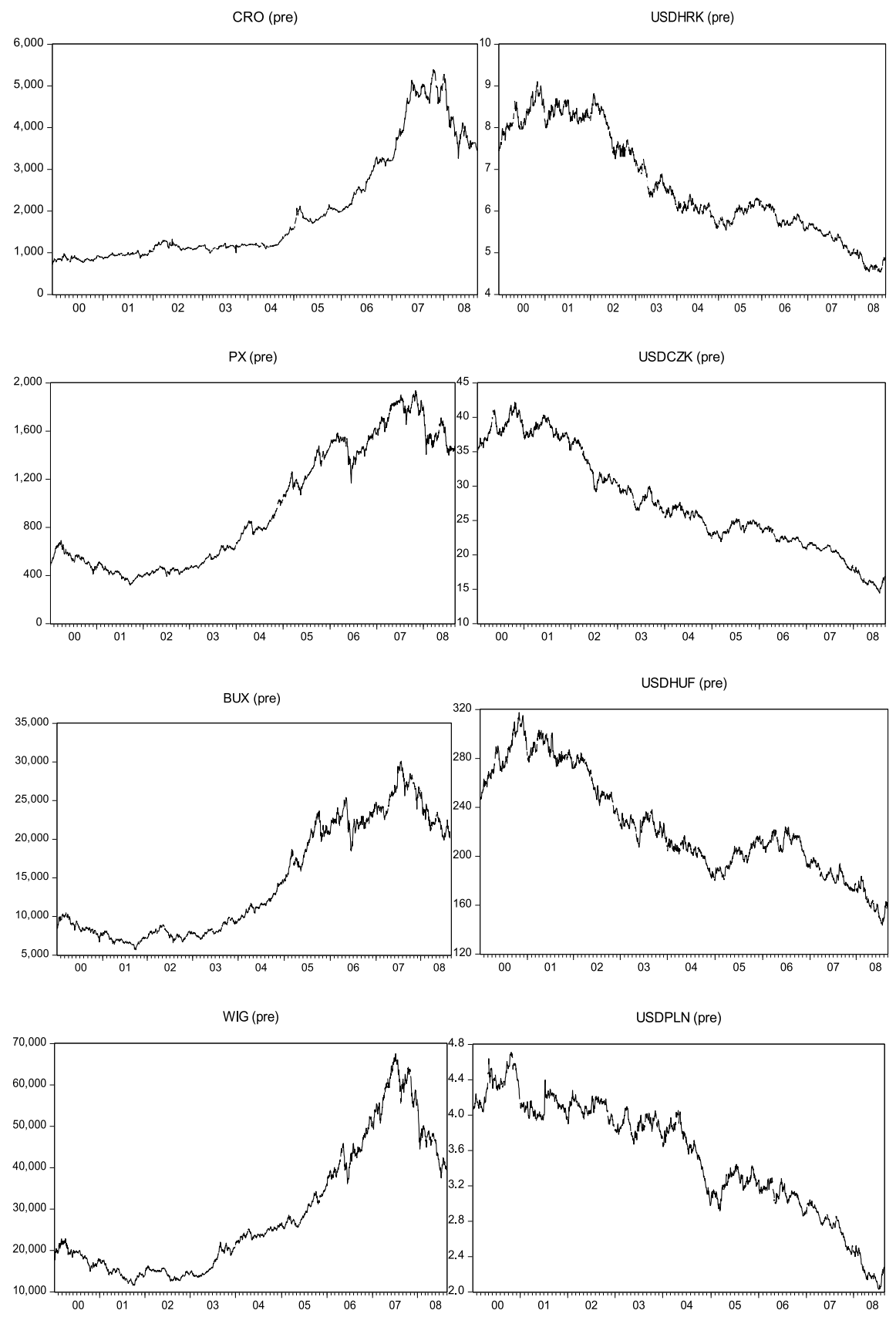
242 AGO THAI HUNG
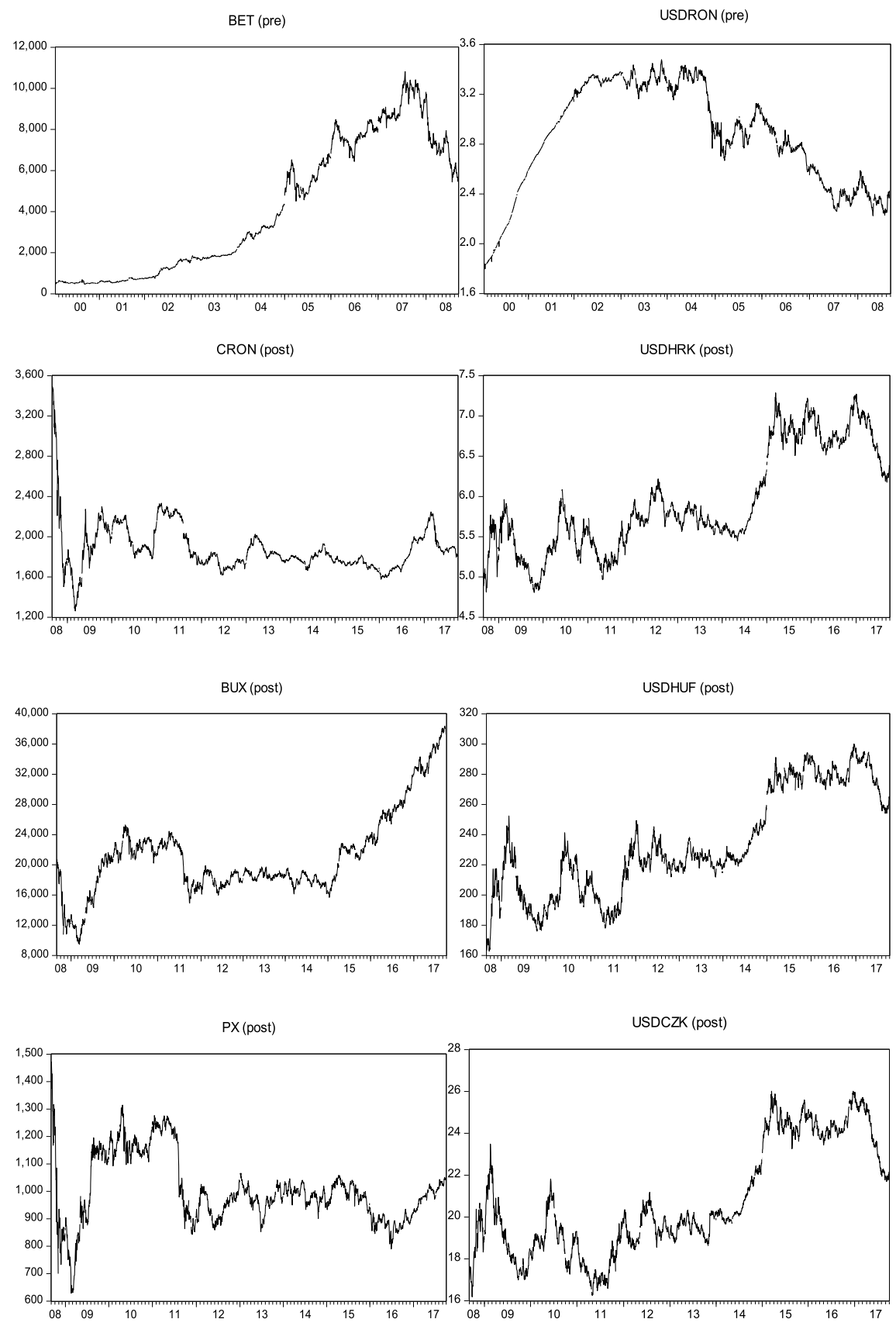

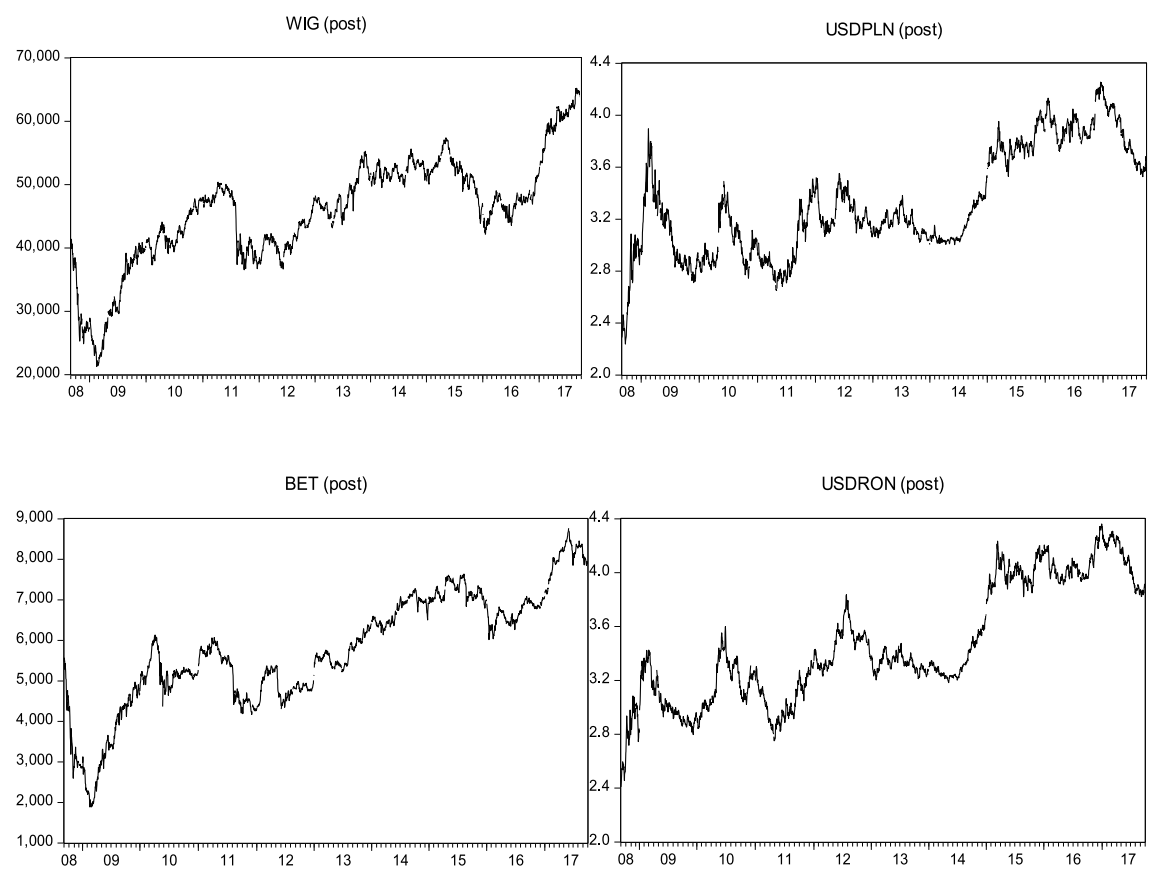

Forrás: a szerző

\subsection{Modellspecifikáció}

Egységgyökteszt

A felhasznált adatsorok stacionaritásának vizsgálatát a szokásos tesztekkel (Phillip-Perron PP, 1988 és Dickey-Fuller ADF, 1979) vizsgáltuk, így biztosítható az eredmények helyessége.

\section{EGARCH-modell}

A részvényhozamok volatilitása, valamint a devizaárfolyamok volatilitása közötti kölcsönöshatást exponenciális általánosított autoregresszív feltételes heteroszkedaszticitás (EGARCH) modellel vizsgáltuk (kifejlesztője: Nelson, 1991). Ez a modell képes az aszimmetrikus továbbgyürüzést kimutatni. A sima GARCH-modell csupán a volatilitás szimmetrikus (pozitív) hatásait képes megragadni, a negatív, tehát aszimmetrikus sokkok kimutatására nem képes, mivel itt a feltételes variancia a késleltetett reziduumok függvénye, nem pedig a jele. Az EGARCH-modellben nincsenek ilyen paraméteri megkötések, így az mind a szimmetrikus, mind az aszimmetrikus sokkokat képes kimutatni. Éppen ezért 
rengeteg tanulmány használta már fel különböző országok példáján az EGARCHmodellt a volatilitás tovagyürüzésének a bizonyítására. Az előzőekben említett tanulmányokat leszámítva a következő munkákban alkalmazták a módszertant: Mishra et al., 2007; Choi et al., 2010; Adiasi et al., 2008; Qayyum-Kamal, 2006; Okpara-Odionye, 2012; Beer-Hebein, 2011. Ebben a tanulmányban az EGARCH $(1,1)$ modell segítségével elemezzük az általunk kiválasztott országok volatilitás átviteli mechanizmusát.

A devizapicról induló volatilitás továbbgyürüződés vizsgáló EGARCH-modell:

$R_{t}=\alpha_{0}+\alpha_{1} R_{t-1}+\alpha_{2} R_{t-1(E R)}+\varepsilon_{t}$

$h_{t(S P)}=\beta_{0}+\beta_{1} h_{t-1}+\beta_{2}\left|\frac{\varepsilon_{t}-1}{\sqrt{h_{t-1}}}\right|+\phi \frac{\varepsilon_{t}-1}{\sqrt{h_{t-1}}}+\delta_{(\operatorname{resid}(E R))}$

Az (1) és a (2) egyenlet azt az EGARCH $(1,1)$ modellt hivatott reprezentálni, amely a devizapiacokról induló, részvénypiacokra ható volatilitást vizsgálja a kiválasztott országokban.

A részvénypiacokról induló volatilitás továbbgyürüződést vizsgáló $E G A R C H$ modell:

$K_{t}=a_{0}+a_{1} K_{t-1}+a_{2} K_{t-1(S P)}+\varepsilon_{t}$

$h_{t(E R)}=\gamma_{0}+\gamma_{1} h_{t-1}+\gamma_{2}\left|\frac{\varepsilon_{t}-1}{\sqrt{h_{t-1}}}\right|+\varphi \frac{\varepsilon_{t}-1}{\sqrt{h_{t-1}}}+\psi_{(\operatorname{resid}(S P))}$ 
3. táblázat

Paraméteregyenletek leírása (1)-(4)

\begin{tabular}{lcc}
\hline Értelmezés & $\mathbf{S}$ & $\mathbf{E}$ \\
\hline Feltételes várható érték & $(1)$ & $(3)$ \\
Feltételes variancia egyenlet & $(2)$ & $(4)$ \\
Hozam & $R_{t}$ & $K_{t}$ \\
Tengelymetszet & $\alpha_{0}$ & $a_{0}$ \\
Előző napi hozamok hatása & $\alpha_{1}$ & $a_{1}$ \\
Devizaárfolyamok változásának hatása & $\alpha_{2}$ & \\
a részvények hozamára & & \\
Részvényhozamok változásának hatása & & $a_{2}$ \\
a devizaárfolyamok hozamára & $\varepsilon_{t}$ & $\varepsilon_{t}$ \\
Hibatényező & $h_{t(S P)}$ & $h_{t(E R)}$ \\
Feltételes variancia logaritmusa & $\beta_{0}$ & $\gamma_{0}$ \\
Konstans volatilitás & $\beta_{1}$ & $\gamma_{1}$ \\
Volatilitás függvénye & $\beta_{2}$ & $\gamma_{2}$ \\
Volatilitás reakciója a hírekre & $\phi$ & $\varphi$ \\
Volatilitás asszimetrikusságának a vizsgálata & $\delta$ & $\Psi$ \\
Volatilitás tovagyűrűzése & $\delta$ &
\end{tabular}

Megjegyzés: S - részvényhozam, E - devizaárfolyam hozama

A volatilitás begyürüzésének a vizsgálata során először a részvény- és devizaárfolyam-hozamok leíró statisztikáit számoltuk, majd elvégeztük a szükséges stacionaritás vizsgálatot ADF- és PP-tesztekkel mindegyik érintett változón. A következő lépésben egy autoregresszív mozgóátlag (ARMA) modell paramétereit becsültük, ezáltal határoztuk meg a várhatóérték-egyenletet. A várhatóérték-egyenlet reziduumainak felhasználásával az ARCH-hatást vizsgáltuk (a khínégyzet szignifikáns értéke az ARCH-hatást jelöli a mögöttes változóban). Az EGARCH-modell csak olyan adatokon használható, amelyeknél fennáll és kimutatható az ARCH-hatás. Az ARCH-hatás esetén az EGARCH-modell segítségével megbecsültük a részvénypiacok és devizapiacok közti volatilitás továbbgyűrüződését. Végezetül reziduális diagnosztikát, ARCH LM-tesztet hajtottunk végre. 


\section{EREDMÉNYEK}

A részvényhozamok, valamint devizahozamok leíró statisztikája és az egységgyökök az 1. és a 2. táblázatban láthatók. A részvényhozamok várható értéke a válság utáni Csehország és Horvátország kivételével mindenhol nullától eltérő, és pozitív értéket mutatott. A varianciák értékea o,69\% (horvát) és 1,62\% (magyar) között alakult. Ehhez hasonlóan a magyar és a lengyel devizapiacoknál volt megfigyelhető a legnagyobb napi átlaghozam az egész megfigyelési periódust tekintve. A ferdeségi és csúcsossági értékek arra utalnak, hogy a hozameloszlások meg sem közelítik a normális eloszlást, ahogy a Jarque-Bera-teszt is statisztikailag mutatja. Végezetül az összes devizahozam és részvényhozam stacionernek bizonyult a megfelelő szignifikanciaszinten (például I(o) 1\%-os szignifikanciaszinten a PPADF statisztikák szerint).

A 4. táblázat a részvény- és devizaárfolyamokban megjelenő ARCH-hatást szemlélteti. Az ARCH-hatás az adatsorban megjelenő autokorrelációt és heteroszkedaszticitást jelzi. Az eredmények alapján kimutatható ARCH-hatás, így az EGARCH $(1,1)$ modell alkalmazható.

A volatiltás tovagyürűzését az $\operatorname{EGARCH~}(1,1)$ modellel vizsgáljuk. Az egyes piacokat országonként külön-külön tekintettük. Először a devizapiacokról induló volatilitás továbbgyürűzését vizsgáltuk meg, majd ezután következett a részvénypiacokról induló volatilitás hatásának az elemzése. Az egyes modelleknél szükséges megfelelő késleltetési időket az Akaike információs kritérium segítségével határoztuk meg. 


\section{4. táblázat}

ARCH-teszt

\begin{tabular}{|c|c|c|c|c|c|}
\hline Országok & $\begin{array}{l}\text { Magyar- } \\
\text { ország }\end{array}$ & $\begin{array}{c}\text { Lengyel- } \\
\text { ország }\end{array}$ & Csehország & Románia & $\begin{array}{l}\text { Horvát- } \\
\text { ország }\end{array}$ \\
\hline \multicolumn{6}{|c|}{ Részvényindexek } \\
\hline \multicolumn{6}{|c|}{ Panel A: Válság előtti időszak } \\
\hline Konstans & $1,254^{*}$ & $1,021^{*}$ & $0,892^{*}$ & $1,525^{*}$ & $1,137^{*}$ \\
\hline $\operatorname{AR}(1)$ & $0,061^{*}$ & $0,042^{* *}$ & $0,071^{*}$ & $0,390^{*}$ & $0,271^{*}$ \\
\hline ARCH teszt & $80,09^{*}$ & $110,57^{*}$ & $141,74^{*}$ & $362,65^{*}$ & $240,30^{*}$ \\
\hline \multicolumn{6}{|c|}{ Panel B: Válság utáni időszak } \\
\hline Konstans & $1,137^{*}$ & $0,579^{*}$ & $0,659^{*}$ & $0,942^{*}$ & $0,544^{*}$ \\
\hline $\operatorname{AR}(1)$ & $0,290^{*}$ & 0,020 & $0,228^{*}$ & $0,306^{*}$ & $0,297^{*}$ \\
\hline ARCH teszt & $363,55^{*}$ & $309,09^{*}$ & $559,10^{*}$ & $411,67^{*}$ & $550,14^{*}$ \\
\hline \multicolumn{6}{|c|}{ Devizaárfolyamok } \\
\hline \multicolumn{6}{|c|}{ Panel A: Válság előtti időszak } \\
\hline Konstans & $0,515^{*}$ & $0,331^{*}$ & $0,402^{*}$ & $0,2085^{*}$ & $0,335^{*}$ \\
\hline $\operatorname{AR}(1)$ & $0,097^{*}$ & $0,137^{*}$ & 0,012 & $0,567^{*}$ & $0,108^{*}$ \\
\hline ARCH teszt & $25,01^{*}$ & $72,17^{*}$ & $21,37^{*}$ & $576,77^{*}$ & $59,96^{*}$ \\
\hline \multicolumn{6}{|c|}{ Panel B: Válság utáni időszak } \\
\hline Konstans & $0,498^{*}$ & $0,408^{*}$ & $0,291^{*}$ & $0,256^{*}$ & $0,276^{*}$ \\
\hline $\operatorname{AR}(1)$ & $0,042^{* *}$ & $0,158^{*}$ & $0,084^{*}$ & 0,038 & $0,173^{*}$ \\
\hline ARCH teszt & $251,82^{*}$ & $403,89^{*}$ & $325,83^{*}$ & $291,60^{*}$ & $151,88^{*}$ \\
\hline
\end{tabular}

Megjegyzések: az ARCH-teszt az ARCH-hatás tesztje.

** jelöli az 5\%-os szignifikanciaszintet, ${ }^{\star}$ a $p<1 \%$-ra utal.

Forrás: a szerző

$\mathrm{Az}$ 5. táblázat az EGARCH-modell eredményeként a várható érték és a feltételesvariancia-egyenletek paramétereit tartalmazza. A várható érték egyenlete alapján a devizapiaci hozamok változása jelentős negatív hatással bírt a magyar és lengyel részvényhozamokra a teljes vizsgálati időszakban, a cseh, román és horvát piacoknál pedig a válság után. Ennél a három országnál a válság előtti időszakban azonban nem volt kimutatható szignifikáns kapcsolat a két piac között. A részvénypiaci negatív hatásból arra tudunk következtetni, hogy a devizapiaco- 
kon történő változások csökkentik a részvénypiacok hozamait, így közvetetten a részvényárfolyamok és a profitabilitás is csökken az érintett országokban. Továbbá ez a negatív hatás a kereskedelmi mérleg és az ország versenyképességének az ingadozásához is vezethet. Ennek eredményeként a reáljövedelmek és a gazdasági növekedés is csökkenhet (Jebran-Iqbal, 2016). Hasonló negatív kapcsolatot mutattak ki Aloui, 2007; Yang-Doong, 2011; Jebran-Iqbal, 2016.

A kutatás eredménye annak a részvényvezérelt modellnek az elméleti előrejelzését támasztja alá, amely szerint a részvény- és a devizahozamok között negatív a kapcsolat. Csehország, Románia és Horvátország esetében a válság előtti időszakban a devizapiaci változások nem hatottak szignifikánsan a részvénypiacra, ami a devizaárfolyam-kockázattal szembeni hatásos fedezeti stratégiákból is eredhet. Empirikus vizsgálatunk további eredményei szerint a részvénypiacok változása és a devizahozamok között gyengén szignifikáns kapcsolat volt a a teljes vizsgált időszakban, kivéve a válság utáni román piacot. Ott a az utóbbi években a részvénypiaci változások szignifikáns negatív hatással vannak a devizahozamokra. Ez a kapcsolat a portfólió egyensúlymodell-magyarázatával áll összhangban, amely szerint a részvénypiaci kereslet-kínálat határozza meg a devizaárfolyamokat, mivel a hazai tőzsdei piaci árak növekedése a befektetőket a külföldi pénzügyi eszközeik eladására és hazai eszközök vételére ösztönzi. Ez a következtetés megegyezik Jebran-Iqbal 2016-os tanulmányának eredményeivel. Mindezek mellett a többi ország részvénypiacairól induló gyenge vagy nem szignifikáns hatás a monetáris megközelítést támasztja alá. Ez a megközelítés azt mondja ki, hogy a részvényárak és a devizaárfolyamok között nincs semmilyen kapcsolat (Ngo Thai Hung, 2017).

A második momentumok kapcsolatának vizsgálatához a varianciaegyenlet $\delta$ koefficiensét elemezzük, amely a devizapiacról induló volatilitás tovagyűrűzését, valamint a kapcsolat aszimmetrikus jellegét mutatja. Az eredmények alapján a teljes időperiódust tekintve Magyarországon, valamint Lengyelországban volt szignifikáns, Romániábanl és Horvátországban pedig csak a válság előtti időszakban. A válság előtti időszakot vizsgálva az együttható Magyarországnál, Lengyelországnál és Romániánál mutatott pozitív értéket, Horvátország esetén azonban negatív eredményt kaptunk. A válság utáni időszakban pedig a magyar és lengyel viszonylatban volt pozitív az értéke. A koefficiens pozitív értéke azt jelenti, hogy a részvénypiacok volatilitása növekszik a devizapiaci volatilitás növekedésének hatására. A negatív érték ennek épp az ellenkezőjét mutatja: a devizapiacok volatilitása csökkenti a részvénypiacok volatilitásának a mértékét. A magyar, cseh és lengyel piacokra kapott eredmények összhangban vannak az alábbi kutatási eredményekkel: Morales, 2008; Aloui, 2007; Valls és Chuliá, 2014).

A $\varphi$ mutató a részvénypiacról induló volatilitás begyürüzését hivatott mérni. Ez az együttható statisztikailag szignifikánsnak mondható Magyarország és Csehor- 
szág tekintetében az egész időszak alatt, azonban Lengyelországban és Romániában a válság előtt, Horvátországban pedig a válság után nem sikerült szignifikáns értéket kimutatni. Mindemellett minden esetben negatív kapcsolatot fedezett fel a modellünk, tehát a részvénypiac volatilitása csökkenti a devizapiacok volatilitását. Fontos megjegyezni, hogy devizapiacról induló volatilitás-továbbgyürüzést nem találtunk Csehországnál, Romániánál és Horvátországnál. Előbbinél ez a teljes megfigyelési periódusra nézve igaz, az utóbbi két országnál pedig csak a válság utáni időszakban. A részvénypiacokról induló volatilitás-tovagyürűzés a válság előtti Lengyelországban és Romániában nem volt megfigyelhető, valamint a válság utáni horvát piacon ebben az esetben sem találtunk szignifikáns kapcsolatot. Ezek az eredmények összhangban vannak Fedorova és Saleem 2009-es kutatásával, azonban ellentmondanak Morales 2008-as eredményeinek.

Röviden összefoglalva az eredményeket: országonként és időszakonként másmás eredményeket kaptunk a volatilitás begyürüzésének vizsgálatakor, mivel a részvényhozamok és devizapiacok közti volatilitás átterjedése idővel változik, pontosabban a válság utáni időszakot tekintve ez a hatás nőtt, hiszen a pénzpiaci integráció a válság utáni időszakban növekedésnek indult.

A kutatás során a következő eredmények születtek: Magyarországon a teljes megfigyelési időszakban, Lengyelországban pedig a válság utáni időszakban kétirányú volatilitásátterjedés figyelhető meg a pénzügyi piacok között, ami a részvénypiaci hatékonytalanságra utal. Horvátországban a válság előtti időszakban, Csehországban pedig a teljes periódusban egyirányú volatilitás-továbbterjedésről beszélhetünk: a részvénypiacok volatilitása hatott szignifikánsan a devizapiacokra. Horvátországban a válság után nem fedeztünk fel volatilitásátterjedést, ami a részvénypiacok és devizaárfolyamok hatékonyságát bizonyítja. Szintén a devizakockázattal szembeni hatékony fedezeti stratégiákról beszélhetünk Csehország, Románia és Horvátország esetében. Előbbinél a teljes megfigyelési időszakban nem tudtuk kimutatni a devizapiacokról induló volatilitás átterjedését, utóbbi kettőnél ez a hatékony fedezéi stratégiák következménye lehet. Végezetül az aszimmetrikus (a részvényhozamoktól a devizaárfolyamok felé irányuló) begyürűzés minden pozitív hozadéka megfigyelhető: a jó hír nagyobb hatást gyakorol a volatilitásra, mint a váratlan rossz hírek. Másfelől a devizaárfolyamtól induló, aszimmetrikus továbbgyűrüzéseknél épp a negatív hírek hatása a nagyobb: ebben az esetben a negatív sokkok nagyobb volatilitást generálnak, mint az azonos nagyságú pozitív sokkok.

A becslési eredmények megbízhatóságát az egyes modellek reziduumaiban megjelenő ARCH-hatások vizsgálatával teszteltük. A vizsgálat célja alapján nullhipotézisünk az ARCH-hatás megléte volt. Az 5. táblázatban láthatók az eredmények, amelyekből kiderül: nagy szignifikanciaszinten kijelenthető, hogy ez a hatás a teljes adatsort tekintve már nincs jelen. Egyedül a válság előtti Romá- 
niánál figyelhető meg ilyen ARCH-hatás azokban az esetekben, ahol a volatilitás a részvénypiacról gyürüzik át a devizapiacra. Ezek az eredmények megfelelnek egy korábbi tanulmány eredményeinek (M. Kamişli és társai, 2015), ezzel elértük kutatásunk végéhez. Az EGARCH-modell használatával sikeresen ki tudtuk mutatni a részvény-, valamint devizapiacok közöttivolatilitás összekapcsoltságát.

\section{5. táblázat}

A részvény- és devizapiacok közötti volatilitás átterjedése

\begin{tabular}{cccccc}
\hline Országok & $\begin{array}{c}\text { Magyar- } \\
\text { ország }\end{array}$ & $\begin{array}{c}\text { Lengyel- } \\
\text { ország }\end{array}$ & Csehország Románia & $\begin{array}{c}\text { Horvát- } \\
\text { ország }\end{array}$ \\
\hline
\end{tabular}

Devizapiacokról induló volatilitás-tovagyürüzés

Panel A: Válság előtti időszak

$\begin{array}{lccccc}\alpha_{0} & 0,041 & 0,053^{* *} & 0,074^{*} & 0,075^{*} & 0,099^{*} \\ \alpha_{1} & 0,033 & 0,061^{*} & 0,049^{* *} & 0,143^{*} & 0,037 \\ \alpha_{2} & -0,083^{* *} & -0,116^{*} & -0,022 & 0,021 & -0,014 \\ \beta_{0} & -0,082^{*} & -0,080^{*} & -0,133^{*} & -0,221^{*} & -0,167^{*} \\ \beta_{1} & 0,943^{*} & 0,979^{*} & 0,939^{*} & 0,916^{*} & 0,924^{*} \\ \beta_{2} & 0,147^{*} & 0,112^{*} & 0,192^{*} & 0,406^{*} & 0,285^{*} \\ \phi & -0,052^{*} & -0,028^{*} & -0,095^{*} & -0,033^{*} & -0,008 \\ \delta & 0,055^{*} & 0,014^{*} & -0,0006 & 0,134^{*} & -0,092^{*} \\ \text { ARCH LM(1) } & 0,019(0,89) & 3,21(0,07) & 4,48(0,03) & 0,39(0,53) & 2,14(0,14)\end{array}$

Panel B: Válság utáni időszak

$\begin{array}{lccccc}\alpha_{0} & 0,031 & 0,033 & 0,005 & 0,027 & 0,015 \\ \alpha_{1} & -0,016 & 0,052^{* *} & 0,024 & 0,067^{*} & 0,055^{*} \\ \alpha_{2} & -0,11^{*} & -0,102^{*} & -0,111^{*} & -0,049^{* *} & -0,066^{*} \\ \beta_{0} & -0,110^{*} & -0,094^{*} & -0,159^{*} & -0,285^{*} & -0,156^{*} \\ \beta_{1} & 0,986^{*} & 0,986^{*} & 0,980^{*} & 0,957^{*} & 0,987^{*} \\ \beta_{2} & 0,152^{*} & 0,123^{*} & 0,209^{*} & 0,393^{*} & 0,200^{*} \\ \phi & -0,063^{*} & -0,045^{*} & -0,067^{*} & -0,062^{*} & -0,036^{*} \\ \delta & 0,016^{* *} & 0,027^{*} & 0,004 & 0,011 & -0,001\end{array}$

$\operatorname{ARCH~LM}(1) \quad 0,63(0,42) \quad 0,76(0,37) \quad 0,61(0,43) \quad 2,38(0,12) \quad 0,06(0,79)$ 
Részvénypiacokról induló volatilitás-tovagyürüzés

Panel A: Válság előtti időszak

$\begin{array}{lccccc}a_{0} & -0,017 & -0,033^{* *} & -0,031^{* *} & 0,078^{*} & -0,036^{*} \\ a_{1} & 0,010 & 0,072^{*} & -0,013 & 0,0004 & -0,072^{*} \\ a_{2} & -0,018 & -0,004 & -0,016 & -0,002 & 0,0002 \\ \gamma_{0} & -0,130^{*} & -0,216^{*} & -1,025^{* *} & -0,100^{*} & -0,057^{*} \\ \gamma_{1} & 0,864^{*} & 0,901^{*} & -0,367^{* *} & 0,993^{*} & 0,995^{*} \\ \gamma_{2} & 0,080^{*} & 0,181^{*} & 0,073^{* *} & 0,123^{*} & 0,069^{*} \\ \varphi & 0,078^{*} & 0,074^{*} & 0,073^{*} & -0,038^{*} & -0,001 \\ \Psi & -0,046^{*} & -0,010 & -0,051^{* *} & -0,004 & -0,015^{*}\end{array}$

$\operatorname{ARCH} \operatorname{LM}(1) \quad 0,48(0,48) \quad 0,60(0,43) \quad 0,01(0,90) \quad 80,7(0,00) \quad 0,02(0,86)$

Panel B: Válság utáni időszak

$\begin{array}{lccccc}a_{0} & 0,011 & 0,016 & 0,017 & 0,011 & 0,014 \\ a_{1} & -0,026 & -0,04^{* *} & -0,005 & -0,008 & -0,032 \\ a_{2} & -0,001 & -0,025 & 0,015 & -0,023^{* *} & -0,018 \\ \gamma_{0} & -0,046^{*} & -0,062 & -0,077^{*} & -0,050^{*} & -0,047 \\ \gamma_{1} & 0,996^{*} & 0,994^{*} & 0,992^{*} & 0,993^{*} & 0,996^{*} \\ \gamma_{2} & 0,058^{*} & 0,078^{*} & 0,091^{*} & 0,057^{*} & 0,047^{*} \\ \varphi & 0,025^{*} & 0,028^{*} & 0,019^{*} & 0,0211^{*} & 0,029^{*} \\ \Psi & -0,016^{*} & -0,022^{*} & -0,021^{*} & -0,012^{*} & -0,007 \\ \text { ARCH LM(1) } & 0,08(0,76) & 1,25(0,26) & 0,34(0,55) & 0,14(0,70) & 4,49(0,03)\end{array}$

Megjegyzés: ${ }^{* *}$ jelöli az 5\%-os szignifikanciaszintet, ${ }^{\star}$ a $p<1 \%$-ra utal. A zárójelben lévő számok a p-értékek.

Forrás: a szerző 


\section{KONKLÚZIÓ}

Ebben a tanulmányban a volatilitás részvény- és devizapiacok közötti átterjedésének dinamikáját kutattuk néhány közép-kelet-európai ország esetében. Ezek a kiválasztott országok Magyarország, Lengyelország, Csehország, Románia és Horvátország voltak. EGARCH-modellt építettünk a válság előtti és utáni devizaárfolyam és részvényárfolyamok vizsgálatára.

Empirikus eredményeink alapján kétirányú volatilitás-továbbgyürüzés figyelhető meg a részvény- és devizapiacok között Magyarországon a teljes megfigyelési időszakban, Lengyelországban pedig a válság utáni időszakban. Az eredmények továbbá egyirányú átterjedést mutattak a részvénypiac felől a válság előtti Horvátországban, valamint Csehországban a teljes időszakot tekintve. A válság utáni Horvátországban nem találtunk volatilitás-továbbterjedést a két pénzügyi piac között. Ez a tovagyűrüzési hatás mindegyik országban aszimmetrikus volt. A részvénypiacokról induló volatilitásátterjedés a válság utáni időszakban csökkent. Az egész megfigyelési időszakot tekintve elmondható, hogy az összes országban megfigyelhető volt a volatilitás tovagyürüzése, a devizapiacok felől induló hatások azonban tartósabbak voltak, mint a részvénypiacokról indulók.

Eredményeink több fontos gazdasági és pénzügyi információval szolgálhatnak a gazdasági döntéshozók és a befektetők számára. Először is a nemzetközi portfóliókezelők és fedezeti üzletkötők jobban megérthetik, hogy a vizsgált két pénzügyi piac milyen kapcsolatban áll egymással; előfordulhat, hogy az egyik piac viselkedése jobban előrejelezhető a másik vizsgált piac adatai segítségével. Másrészt az országon belüli részvény-, valamint devizapiac közötti volatilitástovábbáramlás dinamikájának leírása segítheti a politikai döntéshozókat a gazdasági stabilitás megteremtésében. Végezetül a befektetők számára is érdekesek lehetnek az eredmények a hatékony portfólió összeállításához. Az eredmények felhasználásával kockázatukat csökkenthetik, illetve megtérülésüket növelhetik. 


\section{HIVATKOZÁSOK}

Agrawal, G. - Srivastav, A. K. - Srivastava, A. (2010): A Study of Exchange Rates Movement and Stock Market Volatility. International Journal of Business and Management 5(12), 62-73, https:// doi.org/10.5539/ijbm.v5n12p62.

Beer. F. - Hebein, F. (2011): An Assessment of The Stock Market and Exchange Rate Dynamics in Industrialized and Emerging Markets. International Business Economic Research Journal $7(8)$, 59-70, https://doi.org/10.19030/iber.v7i8.3283.

Baruník, J. - KočEnda, E. -VÁcha, L. (2016): Asymmetric connectedness on the US stock market: Bad and good volatility spillovers. Journal of Financial Markets 27, 55-78, https://doi. org/10.1016/j.finmar.2015.09.003.

Aloui, C. (2007): Price and Volatility Spillovers Between Exchange Rates and Stock indexes for the pre/ and post-Euro period. Quantitative Finance, No. 6, 669-685, https://doi. org/10.1080/14697680701302653.

Choi, D. F. S. - FAng, V. - Fu, T. Y. (2010): Volatility Spillovers Between New Zealand Stock Market Returns and Exchange Rate Changes Before and After the 1997. Asian Financial Crisis. Asian Journal of Finance \& Accounting 1(2), 106-117, https://doi.org/10.5296/ajfa.v1i2.140.

Dornbusch, R. -Fischer, S. (1980): Exchange Rates and The Current Account. American Economic Review 70(5), 960-971.

Dickey, D. - Fuller, W. (1979): Distribution of the estimators for autoregressive time series with a unit root. Journal of the American Statistical Association 74(366a), 427-431, https://doi. org/10.2307/2286348; https://doi.org/10.1080/01621459.1979.10482531.

Diebold, F. X. - Yilmaz, K. (2009): Measuring financial asset return and volatility spillovers, with application to global equity markets. The Economic Journal, 119(534), 158-171, https://doi. org/10.1111/j.1468-0297.2008.02208.x.

Diebold, F. X. - Yilmaz, K. (2012): Better to give than to receive: Predictive directional measurement of volatility spillovers. International Journal of Forecasting, 28(1), 57-66, https://doi.org/10.1016/j. ijforecast.2011.02.006.

Diebold, F. X. - Yilmaz, K. (2014): On the network topology of variance decompositions: Measuring the connectedness of financial firms. Journal of Econometrics 182(1), 119-134, https:// doi.org/10.1016/j.jeconom.2014.04.012.

Frankel, J. A. (1983): Monetary and Portfolio - Balance Models of Exchange Rate Determination. In: Bhandari, J. S. - Putnam, B. H. (eds.): Economic Interdependence and Flexible Exchange Rates. Cambridge: MIT Press.

Fedorova, E. J. - SAleem, K. (2009): Volatility Spillovers Between Stock and Currency Markets: Evidence from Emerging Eastern Europe. Czech Journal of Economics and Finance 60(6), 519533, https://doi.org/10.2139/ssrn.1460645.

Jerban, K. - Iqbal, A. (2016): Dynamics of Volatility Spillover Between Stock Market and Exchange Market: Evidence from Asian Countries. Financial Innovation 2(3), 1-20, https://doi.org/10.1186/ s40854-016-0021-1.

KanAs, A. (2000): Volatility Spillovers Between Stock Return and Exchange Rate Changes: International Evidence. Journal of Business Finance and Accounting 27(3), 447-467, https://doi. org/10.1111/1468-5957.00320.

Morales, L. (2008): Volatility Spillovers Between Stock Returns and Foreign Exchange Rates: Evidence from Four Eastern European Countries. In the conference proceedings of the Financial Management Association (FMA) European Conference, 4-6 June 2008, Prague (Czech Republic). 
Mishra, A. K. - Swain, N. - Malhotra, D. K. (2007): Volatility Spillover Between Stock and Foreign Exchange Markets: Indian Evidence. International Journal of Business 12(3), 343-359.

Mozumder, N. - De Vita, G. - Kyaw, K. - Larkin, C. (2015): Volatility Spillover Between Stock Prices and Exchange Rates: New Evidence Across the Recent Financial Crisis Period. Economic Issues 20(1), 43-64.

KamişLi, M. - KamişLi, S. - Özer, M. (2015): Are Volatility Transmissions Between Stock Market Returns of Central and Eastern European Countries constant or dynamic? Evidence from MGARCH Models. In the conference proceedings of 1oth MIBES Conference, 15-17 October 2015, Larisa (Greece), 190-203.

Valls, N. - Chuliá, H. (2014): Volatility Transmission Between the Stock and Currency Markets in Emerging Asia: The Impact of the Global Financial Crisis. Research Institute of Applied Economics 31, 1-26.

Nelson, D. B. (1991): Conditional Heteroskedasticity in Asset Returns: A New Approach. Econometrica 59(2), 347-370, https://doi.org/10.2307/2938260.

Ngo Thai Hung (2017): An Empirical Test on Linkage between Foreign Exchange Market and Stock Market: Evidence from Hungary, Czech Republic, Poland And Romania. European Scientific Journal 13(31), 25-38, https://doi.org/10.19044/esj.2017.v13n31p25.

Okpara, G. C. - Odionye, J. C. (2012): The Direction of Volatility Spillover between Stock Prices and Exchange Rate: Evidence From Nigeria. Elixir Finance 42, 6410-6414.

QAyyum, A. - Kamal, A. R. (2006): Volatility Spillover Between the Stock Market and the Foreign Market in Pakistan. Pakistan Institute of Development Economics Working Papers 7, https://doi. org/10.2139/ssrn.963308.

Phillips, P. - Perron, P. (1988): Testing for a unit root in time series regression. Biometrika 75(2), 335-346, https://doi.org/10.1093/biomet/75.2.335.

Segal, G. - Shaliastovich, I. - Yaron, A. (2015): Good and bad uncertainty: Macroeconomic and financial market implications. Journal of Financial Economics, 117(2), 369-397, https://doi. org/10.1016/j.jfineco.2015.05.004.

YANG, S-Y. - Doong, S-C.: (2004): Price and Volatility Spillovers Between Stock Prices and Exchange Rates: Empirical Evidence from the G-7 Countries. International Journal of Business and Economics 3(2), 139-153. 